FACTA UNIVERSITATIS

Series: Physical Education and Sport Vol. 16, N ${ }^{\circ} 1,2018$, pp. 85 - 94

https://doi.org/10.22190/FUPES170411008D

Research article

\title{
DIFFERENCES IN THE MECHANICAL CHARACTERISTICS OF THE VERTICAL JUMP BETWEEN ATHLETES IN SPORTS GAMES
}

UDC 796:531.31

\author{
Milan Đokić, Marko Radenković, Ratko Stanković \\ Faculty of Sport and Physical Education, University of Niš, Niš, Serbia
}

\begin{abstract}
The vertical jump is one of the most common ways to evaluate the explosive power of the lower extremities in athletes. For the development of explosive power, plyometric exercises are mostly used as a form of training. The participants were handball players $(N=13)$, volleyball players $(N=13)$ and basketball players $(N=13)$ from city of Nis. They all competed in the highest state competitions. After analyzing all the data, the conclusions are that the mechanical characteristics estimated by the accelerometer are statistically not significantly different in the examined groups of athletes, except in the jump height, and the kinematic characteristics of the vertical jump obtained by the video analysis statistically do not differ significantly, except in the variations of the angular velocity in the hip joint and the ankle.
\end{abstract}

Key words: mechanical characteristics, vertical jump, kinematic, accelerometer

\section{INTRODUCTION}

The use of vertical jumps for the purpose of assessing explosive muscle strength of the legs has been present in professional literature, but also in practice for more than 80 years (Sargent, 1921). Many textbooks, manuals and other publications suggest the use of vertical jumping tests to assess explosive muscle strength (Astrand \& Rodahl, 1986).

Explosive power is defined as the individual ability of the nervous-muscular system to apply strain in the shortest possible time. The notion of explosive power is related to the reactive ability of the neuromuscular apparatus (Verhošanski, 1979). In the definition of explosive force, Zatsiorsky introduced the term reversible force in the theory and practice of athletes, consisting of two successive phases: the eccentric (stretch) and concentric

Received April 11, 2017 / Accepted May 11, 2018

Corresponding author: Milan Đokić

Faculty of Sport and Physical Education, University of Niš, St. Čarnojevića 10a, 18000 Niš, Serbia

Phone: +381 18510900 •E-mail: milandjk@gmail.com 
(shortening). In addition to the regularity of the movement in the rebound, it is important that the body is optimally prepared before reactive training, not only for the prevention of injuries, but also because only an optically innervated muscle can be adapted to the effect of "reactive" training. Preparation before reactive training can be general and special (Weineck, 2000).

In the non-experimental application of plyometric exercises in the pre-competition season, volleyball players Borowsky used six plyometric exercises four weeks before the competitive season and received the expected results in a psychological and physiological way. In the theory and practice of volleyball training, there are several models for the development of explosive leg muscle strength, e.g. Model Chu, (1991). The application of the plyometric method (reversible method - Zatsiorsky) emphasized the need to consider the possibility of its application with youth volleyball players, on the one hand, and the efficiency of a certain set of plyometric exercises on the development of the jump, if it is used after the technical tactical training, on the other.

However, most studies that examined the height of the jump and the measured muscle strength (in Watt, W) have shown that the above-mentioned connection is at best moderate $r \approx 0.50$; for example (Aragon-Vargas \& Gross, 1997), and often not lower (Kukolj, Ropret, Ugarkovic \& Jaric, 1999), thus questioning the validity of the vertical jump height as an index of the explosive muscular strength of man. One of the possible factors responsible for these results is the size of the body (Jaric, Mirkov \& Markovic, 2005; Markovic \& Jaric, 2004). Namely, both the theoretical predictions and the experimental findings clearly show that the muscular strength is in a positive correlation with body size (body mass), while the height of the jump is independent of the size of the body. A large number of studies evaluated the performance of the vertical jump of basketball players at different playing positions (Smith, \& Thomas, 1991). The difference in the skill level of the vertical jump is in a direct relation with the height of the jump, which was confirmed by the study, which included the eight best players in all positions and the rest of the team (Hoare, 2000; Latin, Berg, \& Baechle, 1994). In recent research (Delextrat, \& Cohen, 2008), vertical jump values showed an $8.8 \%$ higher value among elite and average players. The research of Berg \& Latin (1995) compares the median values of the vertical jump between basketball players and soccer players. It was concluded that there is similarity in these abilities, but that strength values were greater among soccer players.

Handball is a powerful sport, a sport with a focus on running, jumping, sprinting, throwing, pushing and blocking (Gorostiaga, Granados, Ibañez, González-Badillo, \& Izquierdo, 2004). Since elite handball demands are increasing every day, it is necessary to maintain an adequate level of force and strength during the season (Buchheit, et al., 2008; Marques, \& González-Badillo, 2006). A combination of speed training and explosive power is necessary to improve the maximum speed of jumping and jumping height (Chelly, et al., 2009; Christou, et al., 2006), as well as the development of maximum anaerobic abilities and explosive capacities (Buchheit, et al., 2009; Buchheit, et al 2008; McMillan, Helgerud, Macdonald, \& Hoff, 2005). Reduced maximum power and explosive strength were observed in 5.5 seconds of strength training, suggesting that hand-to-hand training requires weight training and strength training (Jensen, Jacobsen, Hetland, \& Tveit, 1997). 
Considering all the above, as well as the fact that in the performance of the vertical jump the athlete starts his own body mass, our assumption is that the height of the jump is a valid index of muscular strength normalized to the size of the body.

\section{METHODS}

\section{The sample of participants}

The participants in this study were athletes from the best clubs in city of Niš: handball players from the handball club "Železničar", a member of the Super Handball League of Serbia (SRLS), basketball players from the basketball club "Konstantin", who competed in the first basketball league of Serbia (KLS), and volleyball players from the volleyball club "Niš", which is a member of the first league of Serbia. The total number of participants was $39(13+13+13)$. Participants had to satisfy the requirements that they had participated in their selected sport longer than 5 years, that they were seniors, healthy, and involved in the training process.

\section{Measuring instruments}

The sample of measuring instruments for the assessment of body characteristics of the sample:

- Body height (BH in cm),

- Body mass (BM in kg).

The sample of measuring instruments for the assessment of mechanical characteristics by the accelerometer:

- Force $(\mathrm{F}$ in $\mathrm{N})$,

- Power (P in W),

- Speed (V in cm /s),

- Jumping height ( $\mathrm{H}$ in $\mathrm{cm})$.

The sample of measuring instruments for the assessment of mechanical characteristics by kinematic analysis:

- Maximum angular velocity in the ankle joint (MAVAJ in deg/s),

- Maximum angular velocity in the knee joint (MAVKJ in deg/s),

- Maximum angular velocity in the hip joint (MAVHJ in deg/s).

\section{Statistical analyses}

All the kinematic parameters were obtained using the Casio FX fast motion camera, with a recording speed of 300 frames per second. Video processing and digitization was done using the kinematic analysis program HUMAN HMA Technology Inc. In addition to the accelerometer, the participants also had reflective markers at representative points using automatic digitization. With graphs of the change in the angular velocity values, maximum values were obtained in the phase of the eccentricity and the concentration. Each video consisted of over 550 video frames and for each attempt angular values and corner angles in the lower limb joints were calculated. 
In this research, basic, descriptive data processing was used to determine the measures of central tendency (arithmetic mean) and measurements of variability (standard deviation, range, maximal and minimal result). To verify the normal distribution of results, skewness, kurtosis and the Kolmogorov Smirnov test were used. A univariate analysis of variance (ANOVA) and multivariate variance analysis (MANOVA), as well as a post hoc analysis - the least significant difference test (LSD) were used to determine differences in arithmetic means among the groups of athletes.

\section{RESULTS}

Table 1 Multivariate analysis of mechanical characteristics of athletes in sports games estimated by the accelerometer

\begin{tabular}{cccccc}
\hline & Value & $\mathrm{F}$ & $\begin{array}{c}\text { Hypothesis } \\
\text { df }\end{array}$ & $\begin{array}{c}\text { Error } \\
\text { df }\end{array}$ & Sig. \\
\hline Wilks' Lambda & 0.72 & $1.492 \mathrm{a}$ & 8.00 & 66.00 & 0.18 \\
\hline
\end{tabular}

In Table 1 we see the results of a multivariate variance analysis for a set of variables used to evaluate the mechanical characteristics using an accelerometer. The value of Wilks' Lambda of 0.72 , with the F approximation of 1.492 and 8 degrees of freedom, which gives a statistically significant difference at the level of 0.18 among the tested groups of athletes.

Table 2 Univariant analysis of mechanical characteristics of athletes in sports games estimated by the accelerometer

\begin{tabular}{rccrrrr}
\hline Source & $\begin{array}{c}\text { Dependent } \\
\text { Variable }\end{array}$ & $\begin{array}{c}\text { Type III } \\
\text { Sum of Squares }\end{array}$ & df & $\begin{array}{c}\text { Mean } \\
\text { Square }\end{array}$ & F & Sig. \\
\hline \multirow{6}{*}{ Sport } & $\mathrm{F}$ & 42.40 & 2.00 & 21.20 & 1.17 & 0.32 \\
& $\mathrm{P}$ & 243.36 & 2.00 & 121.68 & 0.56 & 0.58 \\
& $\mathrm{~V}$ & 1434.51 & 2.00 & 717.26 & 0.38 & 0.69 \\
& $\mathrm{H}$ & 161.91 & 2.00 & 80.96 & 3.01 & 0.06 \\
\hline
\end{tabular}

In order to determine which variables contributed to the significance of the differences, a non-univariate analysis of variance was calculated, which is shown in the following table 2 . It is noted that only variable $\mathrm{H}$ of jumping height has a high level of significance of 0.06 , which has given the greatest contribution to the difference of all mechanical characteristics among the tested groups of athletes.

Table 3 Post hoc analysis - the least significant difference test (LSD)

\begin{tabular}{ccccc}
\hline Variable & (I) Sport & (J) Sport & $\begin{array}{c}\text { Difference } \\
\text { arithmetic mean (I-J) }\end{array}$ & Sig. \\
\hline \multirow{4}{*}{} & \multirow{2}{*}{ Basketball players } & Volleyball players & -1.30 & 0.53 \\
& & Handball players & 3.52 & 0.09 \\
$\mathrm{H}$ & \multirow{2}{*}{ Volleyball players } & Basketball players & 1.30 & 0.53 \\
& & Handball players & $4.823^{*}$ & 0.02 \\
& \multirow{2}{*}{ Handball players } & Basketball players & -3.52 & 0.09 \\
& & Volleyball players & $-4.823^{*}$ & 0.02 \\
\hline
\end{tabular}


In the subsequent analysis of variance, a post hoc analysis (table 1.2) of the smallest significant differences for the variation of jump height $\mathrm{H}$ was calculated. Comparing pairs of examined athletes, it was noted that the difference in jumping height between volleyball players and handball players is statistically significantly different (0.02) and that it contributed to the statistically significant difference at the univariate level. In other pairs of athletes, there was no statistically significant difference in the arithmetic mean of the height of the jump, although there is a large difference between the basketball players and the handball players.

Table 4 Multivariate analysis of mechanical characteristics of athletes in sports games estimated by the kinematic method

\begin{tabular}{cccccc}
\hline & Value & F & $\begin{array}{c}\text { Hypothesis } \\
\text { df }\end{array}$ & $\begin{array}{c}\text { Error } \\
\text { df }\end{array}$ & Sig. \\
\hline Wilks' lambda & 0.54 & $1.854 \mathrm{a}$ & 12.00 & 62.00 & 0.06 \\
\hline
\end{tabular}

Table 4 shows the results of the multivariate variance analysis for a set of variables which were used to evaluate the mechanical characteristics using the kinematic method. The value of Wilks 'Lambda of 0.54 , with F approximation of 1.854 and 12 degrees of freedom, gives a statistically significant difference at the level of 0.06 among the tested athletes' groups.

Table 5 Univariant analysis of the mechanical characteristics of athletes in sports games estimated by the kinematic method

\begin{tabular}{llccrcc}
\hline \multirow{2}{*}{ Source } & $\begin{array}{c}\text { Dependent } \\
\text { Variable }\end{array}$ & $\begin{array}{c}\text { Type III } \\
\text { Sum of Squares }\end{array}$ & df & \multicolumn{1}{c}{$\begin{array}{c}\text { Mean } \\
\text { Square }\end{array}$} & F & Sig. \\
\hline \multirow{5}{*}{ Sport } & MAVHJEG & 14626.31 & 2.00 & 7313.15 & 3.03 & 0.06 \\
& MAVHJCG & 1596.05 & 2.00 & 798.03 & 0.45 & 0.64 \\
& MAVKJEG & 4850.00 & 2.00 & 2425.00 & 1.52 & 0.23 \\
& MAVKJCG & 6053.90 & 2.00 & 3026.95 & 0.96 & 0.39 \\
& MAVAJEG & 188.77 & 2.00 & 94.39 & 0.21 & 0.81 \\
& MAVAJCG & 34699.13 & 2.00 & 17349.56 & 6.22 & 0.01 \\
\hline
\end{tabular}

In order to determine the variables that contributed to the significance of the differences, a univariate analysis of the variance was calculated, as shown in Table 5. It can be noted that the variables MAVHJEG and MAVAJCG have a high level of significance of 0.06 and 0.01 , respectively. They made the greatest contribution to the difference between all the mechanical characteristics among the groups of athletes examined at the multivariate level. 
Table 6 Post hoc analysis - the least significant difference test (LSD)

\begin{tabular}{|c|c|c|c|c|}
\hline Dependent variable & (I) Sport & (J) Sport & $\begin{array}{c}\text { Difference } \\
\text { arithmetic mean (I-J) }\end{array}$ & Sig. \\
\hline \multirow{6}{*}{ MAVHJEG } & \multirow{2}{*}{ Basketball players } & Volleyball players & $-42.77^{*}$ & 0.03 \\
\hline & & Handball players & -3.62 & 0.85 \\
\hline & \multirow{2}{*}{ Volleyball players } & Basketball players & $42.77 *$ & 0.03 \\
\hline & & Handball players & $39.15^{*}$ & 0.05 \\
\hline & \multirow{2}{*}{ Handball players } & Basketball players & 3.62 & 0.85 \\
\hline & & Volleyball players & $-39.15^{*}$ & 0.05 \\
\hline \multirow{6}{*}{ MAVAJCG } & \multirow{2}{*}{ Basketball players } & Volleyball players & -29.31 & 0.17 \\
\hline & & Handball players & $43.31 *$ & 0.04 \\
\hline & \multirow{2}{*}{ Volleyball players } & Basketball players & 29.31 & 0.17 \\
\hline & & Handball players & $72.62 *$ & 0.00 \\
\hline & \multirow{2}{*}{ Handball players } & Basketball players & $-43.31 *$ & 0.04 \\
\hline & & Volleyball players & $-72.62 *$ & 0.00 \\
\hline
\end{tabular}

In the subsequent analysis of variance, a post hoc analysis of the smallest significant differences for the variables MAVHJEG and MAVAJCG was calculated, shown in Table 6. Comparing the pairs of the studied athletes, a statistically significant difference in angular velocities in the hip joint in the eccentric MAVHJEG phase between volleyball and handball players, and between the volleyball players and basketball players $(0.05$, 0.03 , respectively) was noted, and that it contributed to a statistically significant difference at the univariate level. No statistically significant difference in arithmetic means for this variable was obtained for the basketball players and handball players.

Regarding the corner velocity in the hips in the concentric phase of the vertical jump MAVAJCG, based on the post hoc analysis of the smallest significant differences, from Table 6 it can be seen that all pairs of investigated athletes differ statistically significantly, except basketball players and volleyball players.

\section{DISCUSSION}

The aim of this study was to determine the differences in the mechanical characteristics of the vertical jump in basketball, handball and volleyball seniors. On a sample of athletes in sports, basketball, handball and volleyball, competing in the highest national ranking of the competition, an examination was performed to evaluate the values of the mechanical characteristics of the vertical jump using the accelerometer method and the kinematic method. The obtained values were statistically processed in order to determine the differences in the tested variables.

Based on the results of a multivariate variance analysis of mechanical characteristics estimated by accelerometer (table 1), statistically significant difference where fined at the level of 0.18 among the tested groups of athletes. Base on that, univariant analysis of the same mechanical characteristics estimated by accelerometer (table 2) was done, and the results indicate that there is significant difference only in one variable and that is jumping height $(\mathrm{H})$ with $\mathrm{Sig}$. $\geq 0.06$ which was confirmed in the previous study (Peña López, 
Moreno-Doutres, Coma Bau, \& Cook, 2018). Since these athletes, which are compared among themselves, are from three different sports (basketball, volleyball and handball) in which the vertical jump is not represented equally and the height does not have the same importance, these kind of results are expected. With that sad, the emphasis on the increasing height of vertical jump during practices is not the same in these sports. Variable jumping height $(\mathrm{H})$ was further analyzed by post hock analyze - LSD (table 3) after which it was concluded that the only significant difference exists between volleyball and handball players Sig. $\geq 0.02$. The fact that handball is a sport with continuous body contact handball players usually have big body weight and that usually have a negative influence on vertical jump performance (Hermassi, Chelly, Tabka, Shephard, \& Chamari, 2011). On the other hand, volleyball is non-contact sport and because of lack of body contact players do not need to develop high body mass. Vertical jump and explosive strength are important in volleyball game because there are the basis of attack (spike) and defense (block). Also, the reason for these results can be the similarities of the test and jumps movements of volleyball players and largest number of vertical jumps per player in one game (Sheppard, Nolan, \& Newton, 2012; Sheppard et. all, 2008; Fontani, Ciccarone, \& Giulianini, 2000) when comparing with basketball (McInnes, Carlson, Jones, \& McKenna, 1995) and handball (Póvoas et. all, 2012). Jumping performance differences are attributable to different training backgrounds (Kollias, Panoutsakopoulos, \& Papaiakovou, 2004) and the height of the vertical jump is strongly correlated with the strength of the lower limbs explosive strength (de Ruiter, de Korte, Schreven, \& De Haan, 2010). With that sad plyometric is the most usable training for developing explosive strength of lower limps. The execution of plyometric jumps aiming for maximum jump height in the shortest possible contact time led to an improvement of power output.

When it comes to results of the mechanical characteristics estimated by kinematic method they are also processed with multivariate analysis (table 4) and the statistically significant difference can be seen at the level of 0.06 among the athletes' groups. After univariate analysis (table 5) statistically significant difference was observed in two variables (MAVHJEG Sig. $\geq 0.06$ and MAVAJCG Sig. $\geq 0.01$ ), which have been further processed by LSD analyze (table 6). Statistically significant difference in angular velocities in the hip joint in the eccentric phase (MAVHJEG) was found between volleyball and handball players Sig. $\geq 0.05$, and between volleyball players and basketball players Sig. $\geq$ 0.03 . The release time of the stored elastic energy can be optimized by increasing the amount of activity of the eccentric muscle (McBride, McCaulley, \& Cormie, 2008; Finni, Komi, \& Lepola, 2000). These results are based on the fact that maximal vertical jumps need a greater engagement of the hip extensor muscles (Giatsis, Panoutsakopoulos, \& Kollias, 2018; Bobbert \& Casius, 2005; Lees, Vanrenterghem, \& De Clercq, 2004) and we saw that volleyball players have the best result in jump height $(\mathrm{H})$.

When it comes to second variable, the angle velocity in the ankle joint in the concentric phase of the vertical jump (MAVAJCG), statistically significant difference was found between handball players and other athletes (Basketball players Sig. $\geq 0.04$ and Volleyball players Sig. $\geq 0.00$ ). The results are also showing that handball players have lover values then other athletes. This can be the reason of vertical jump height itself. Because vertical jump is classic plyometric move it should be done explosively as possible. Fast concentric contraction also results in rapid eccentric contraction which causes high velocity in the joints of the lower extremities. In a previous studie (Toumi, 
Best, Martin, \& Poumarat, 2004) has been suggested that improvments in vertical jump may be because of increased activation in the eccentric phas in leg joints

\section{CONCLUSION}

The aim of this research was to determine the differences in the mechanical characteristics of the vertical jump in basketball, handball and volleyball seniors.

On a sample of athletes in sports, basketball, handball and volleyball, competing in the highest national ranking of the competition, an examination was performed to evaluate the values of the mechanical characteristics of the vertical jump using the accelerometer method and the kinematic method. The obtained values were statistically processed in order to determine the differences in the tested variables. Based on the results and its discussion, the following conclusions can be drawn:

- The mechanical characteristics estimated by the accelerometer are statistically not significantly different in the studied groups of athletes, except in the jump height.

- The kinematic characteristics of the vertical jump obtained by the video analysis statistically do not differ significantly, except in the variations of the angular velocity in the hip joint and in the ankle.

Acknowledgement: The research was conducted within the project Biomechanical efficiency of top Serbian athletes (ON179019) funded by the Ministry of Education, Science and Technological Development of the Republic of Serbia.

\section{REFERENCES}

Aragon-Vargas, L. F., \& Gross, M. (1997). Kinesiological factors in vertical jump performance: differences among individuals. Journal of Applied Biomechanics, 13, 24-44.

Astrand, P. O., \& Rodahl, K. (1986.). Textbook of work physiology. New York: McGraw-Hill.

Bobbert, M. F., \& Casius, L. J. R. (2005). Is the effect of a countermovement on jump height due to active state development? Medicine and Science in Sports and Exercise, 37(3), 440 - 446.

Buchheit, M., Laursen, P. B., Kuhnle, J., Ruch, D., Renaud, C., \& Ahmaidi, S. (2009). Game-based training in young elite handball players. International Journal Sports Medicine, 30, 251-258.

Buchheit, M., Millet, G.P., Parisy, A., Pourchez, S., Laursen, P.B., \& Ahmaidi, S. (2008). Supramaximal training and postexercise parasympathetic reactivation in adolescents. Medicine and Science in Sports and Exercise, 40, 362-371.

Chelly, M.S., Fathloun, M., Cherif, N., Ben Amar, M., Tabka, Z., \& Van Praagh, E. (2009). Effects of a backsquat training program on leg power, jump- and sprint performances in junior soccer players. The Journal of Strength \& Conditioning Research, 23, 2241-2249.

Christou, M., Smilios, I., Sotiropoulos, K., Volaklis, K., Pilianidis, T., \& Tokmakidis, S.P. (2006). Effects of resistance training on the physical capacities of adolescent soccer players. The Journal of Strength \& Conditioning Research, 20, 783-791.

Chu, D.A. (1991). Jumping into plyometrics. Champaign, IL: Leisure Press.

de Ruiter, C. J., de Korte, A., Schreven, S., \& De Haan, A. (2010). Leg dominancy in relation to fast isometric torque production and squat jump height. European journal of applied physiology, 108(2), 247.

Delextrat, A., \& Cohen, D. (2008). Physiological testing of basketball players: toward a standard evaluation of anaerobic fitness. The Journal of Strength \& Conditioning Research, 22 (4), 1066-1072.

Finni, T., Komi, P. V., \& Lepola, V. (2000). In vivo human triceps surae and quadriceps femoris muscle function in a squat jump and counter movement jump. European journal of applied physiology, 83(4-5), 416-426. 
Fontani, G., Ciccarone, G., \& Giulianini, R. (2000). Nuove regole di gioco ed impegno fisico nella pallavolo. $S$ dello Sport, 19(50), 14-20.

Giatsis, G., Panoutsakopoulos, V., \& Kollias, I. A. (2018). Biomechanical differences of arm swing countermovement jumps on sand and rigid surface performed by elite beach volleyball players. Journal of sports sciences, 36(9), 997-1008.

Gorostiaga, E.M., Granados, C., Ibáñez, J., \& Izquierdo, M. (2005). Differences in physical fitness and throwing velocity among elite and amateur male handball players. International Journal of Sports Medicine, 26, 225-232.

Gorostiaga, E.M., Granados, C., Ibañez, J., González-Badillo, J.J., \& Izquierdo, M. (2006). Effects of an entire season on physical fitness changes in elite male handball players. Medicine and Science in Sports and Exercise, 38, 357-366.

Hermassi, S., Chelly, M. S., Tabka, Z., Shephard, R. J., \& Chamari, K. (2011). Effects of 8-week in-season upper and lower limb heavy resistance training on the peak power, throwing velocity, and sprint performance of elite male handball players. The Journal of Strength \& Conditioning Research, 25(9), 2424-2433.

Hoare, D.G. (2000). Predicting success in junior elite basketball players - the contribution of anthropometic and physiological attributes. Journal of Science and Medicine in Sport, 3(4), 391-405.

Jaric, S., Mirkov, D., \& Markovic, G. (2005.). Normalizing physical performance tests for body size: a proposal for standardization. Journal of Strength and Conditioning Research, 19, 467-474.

Jensen, J., Jacobsen, S.T., Hetland, S., \& Tveit, P. (1997). Effect of combined endurance, strength and sprint training on maximal oxygen uptake, isometric strength and sprint performance in female elite handball players during a season. International Journal of Sports Medicine, 18, 354-358.

Kollias, I., Panoutsakopoulos, V., \& Papaiakovou, G. (2004). Comparing jumping ability among athletes of various sports: vertical drop jumping from 60 centimeters. The Journal of Strength \& Conditioning Research, 18(3), 546-550.

Kukolj, M., Ropret, R., Ugarkovic, D., \& Jaric, S. (1999.). Anthropometric, strength, and power predictors of sprinting performance. Journal of Sports Medicine and Physical Fitness, 39, 120-122.

Lees, A., Vanrenterghem, J., \& De Clercq, D. (2004). The maximal and submaximal vertical jump: Implications for strength and conditioning. Journal of Strength and Conditioning Research, 18(4), 787 791.

Latin, R.W., Berg, K., \& Baechle, T. (1994). Physical and performance characteristics of NCAA division I male basketball players. Journal of Strength \& Conditioning Research, 8(4), 214-218.

Linthorne, N. P. (2001). Analysis of standing vertical jumps using a force platform. American Journal of Physics, 69(11), 1198-1204

Marques, M.C., \& González-Badillo, J.J. (2006). In-season resistance training and detraining in professional team handball players. Journal of Strength \& Conditioning Research, 20, 563-571.

McBride, J. M., McCaulley, G. O., \& Cormie, P. (2008). Influence of preactivity and eccentric muscle activity on concentric performance during vertical jumping. The Journal of Strength \& Conditioning Research, 22(3), 750-757.

McInnes, S. E., Carlson, J. S., Jones, C. J., \& McKenna, M. J. (1995). The physiological load imposed on basketball players during competition. Journal of sports sciences, 13(5), 387-397.

McMillan, K., Helgerud, J., Macdonald, R., \& Hoff, J. (2005). Physiological adaptations to soccer specific endurance training in professional youth soccer players. British Journal of Sports Medicine, 39, 273-277.

Peña López, J., Moreno-Doutres, D., Coma Bau, J., \& Cook, M. (2018). Anthropometric and fitness profile of high-level basketball, handball and volleyball players. Revista Andaluza de Medicina del Deporte, 11(1), 30-35.

Póvoas, S. C., Seabra, A. F., Ascensão, A. A., Magalhães, J., Soares, J. M., \& Rebelo, A. N. (2012). Physical and physiological demands of elite team handball. The Journal of Strength \& Conditioning Research, 26(12), 3365-3375.

Sargent, D.A. (1921.). The physical test of a man. American Physical Education Review, 26, 188-194.

Smith, H.K., \& Thomas, S.G. (1991). Physiological characteristics of elite female basketball players. Canadian Journal of Sport Sciences, 16(4), 289-295.

Sheppard, J. M., Cronin, J. B., Gabbett, T. J., McGuigan, M. R., Etxebarria, N., \& Newton, R. U. (2008). Relative importance of strength, power, and anthropometric measures to jump performance of elite volleyball players. The Journal of Strength \& Conditioning Research, 22(3), 758-765. 
Sheppard, J. M., Nolan, E., \& Newton, R. U. (2012). Changes in strength and power qualities over two years in volleyball players transitioning from junior to senior national team. The Journal of Strength \& Conditioning Research, 26(1), 152-157.

Toumi, H., Best, T. M., Martin, A., \& Poumarat, G. (2004). Muscle plasticity after weight and combined (weight+ jump) training. Medicine \& Science in Sports \& Exercise, 36(9), 1580-1588.

Weineck, J. (2000). Optimales training. 11. Auflage. Balingen: Spitta Verlag GmbH.

Zatsiorsky, V.M. (1995). Science and practice of strength training. Champaign, IL: Human Kinetics.

\section{RAZLIKE U MEHANIČKIM KARAKTERISTIKAMA VERTIKALNOG SKOKA IZMEĐU SPORTISTA}

Vertikalni skok je jedan od najčešćih načina za procenu eksplozivne snage donjih ekstremiteta kod sportista. Za razvoj eksplozivne snage, piliometrijske vežbe se uglavnom koriste kao vid treninga. Ispitanici su bili rukometaši $(N=13)$, odbojkaši $(N=13)$ i košarkaši $(N=13)$ iz grada Niša. Svi su se takmičili u najvišem rangu državnog takmičenja. Posle analize svih prikupljenih podataka zaključeno je da mehaničke karakteristike procenjenim akcelerometrom nisu statistički značajne u ispitivanim sportskim grupama, osim u visini skokova, a kinematičke karakteristike vertikalnog skokova dobijene video analizom, statistički ne pokazuju značajnu razlikzu, izuzev u varijacijama ugaone brzine u zglobu kuka u skočnom zglobu.

Ključne reči: mehaničke karakteristike, vertikalni skok, kinematika, akcelerometar 